\title{
Pilot study on fields with high exposure to psychosocial risk factors
}

\author{
Raluca Maria Iordache*, Viorica Petreanu, and Delia Cristina Mihăilă \\ National Research and Development Institute for Occupational Safety and Health "Alexandru \\ Darabont", Ergonomics Department, Ghencea Blvd. 35A, sector 6, Bucharest, Romania
}

\begin{abstract}
A pilot study concerning psychosocial risk factors that could determine work related stress and effects on work behaviour and health state was developed involving five fields of activity with high exposure on work related stress (education, health, transport, banking, financial consultancy). The study aimed to identify the main specific psychosocial risk factors in every of the five fields, in order to substantiate a method for assessing the risk factors for work related stress. The study used a complex ergonomic methodology, and one of the main instruments used to identify psychosocial factors was the Romanian version of The Copenhagen Psychosocial Questionnaire (COPSOQ).
\end{abstract}

\section{1 introduction}

The European and international policy in the safety and health at work area and consequently the national policies have to adapt themselves to the changes, emerging demands and occupational risks in order to promote a real well-being at work of physical, psychical and social nature that is not measured only by the absence of work accidents and occupational diseases but also by providing the physical, mental and psychosocial wellbeing. $[2,4,5]$

In the 21 st century the work place is a rapid, dynamic, highly incentive environment resulting in a great number of benefits and opportunities for workers. But, at the same time the continuous changing requirements of the working world and work places give rise to several new psychosocial risks that can increase the occupational stress level, especially for those working under pressure. [1]

The last decades have proved that occupational stress can have unwanted consequences both for the personnel's safety and organization's "health". [6]

The continuously changing world of work makes increase the requirements on workers; efforts and higher pressure between professional and extra-professional life are factors that

* Corresponding author: iorraluca@yahoo.com 
contribute to stress at work. Studies show that 50 to $60 \%$ of the total loss working days are due to stress. Preventing and managing stress at work require interventions at the organization level, the organization being the cause of stress. Beside the stress situations, the psychosocial risks are more and more present, such concept including every work context leading to various forms of individual and/or collective bad state, suffering at work and/or physical or mental pathology. Consequently, at European and international level concerns have increased as for putting into evidence the psychosocial and stress factors as risks factors for the comfort, safety and health of the personnel involved in various modern professional work activities. The outcomes of various inquiries, reports and action plans of different European organizations acting in the safety and health at work area result in several conclusions, directions and recommendations on the prevention policy of psychosocial risk factors. The available information underlines that the developed actions, according to the specific national conditions and procedures are not only welcome, but also possible. [3]

Thus, the necessity of initiating a reliable strategy and policy at the national level, adopting competent decisions to adapt/complete regulation in the safety and health at work area to allow organizations/companies implement measure to reduce/eliminate occupational risks of psychosocial nature and protect the personnel against their action. Such approach supposes the integration of the occupational stress management in the general company safety and health at work management, necessitating a national policy and an appropriate regulation framework. [7]

\section{Methods}

\subsection{Aims}

The study aimed to identify the main specific psychosocial risk factors in five fields of activity with high exposure to work related stress (education, health, transports, banking, financial consultancy) [4].

\subsection{Methodology}

The following techniques have been used for identification and evaluation of occupational psychosocial factors, as stress factors:

- Copenhagen Psychosocial Questionary (COPSOQ) - Romanian version;

- DATO Questionnaire, for evaluation of individual vulnerability to stress;

- JCQ Questionnaire (,Karasek - Job Content Questionnaire”), for evaluation of workload content.

\subsubsection{Participants}

Investigated subjects: 1.368 persons

Region: Ilfov (12.76\%); Sibiu (18.64\%); Timiș (16.50\%); Iași (26.36\%); Cluj (25.29\%); No answer $(0.45 \%)$.

Age: $18-25$ yrs (6.11\%); 25-30 yrs (13.83\%); 31-35yrs (15.97\%); 36-45yrs (28.57\%); $45-55 y r s(27.81 \%) ;>55 y r s(7,71 \%)$.

Fields of activity: Transport (2.71\%); Education (14.44\%); Health (21.93\%); Banking (9.78\%); Financial consultancy (11.14\%). 
Seniority in activity: $>1$ year $(3.44 \%) ; 1-5$ years $(3.74 \%) ; 5-10$ years $(7.41 \%) ; 10$ 15 years $(26.36 \%) ; 15$ - 20 years $(16.12 \%) ; 20$ - 30 years $(28.57 \%)$; > 30 years $(12.83 \%)$.

\section{Results}

In relation to the level and symptomatology of stress, as well as the level of psychosocial risk factors, identified through Copenhagen Questionnaire (COPSOQ) și JCQ Questionnaire, the situation is presented in the following table and figures (Table 1 and Fig. 1 and 2):

Table 1. Levels of psychosocial risk factors (COPSOQ)

\begin{tabular}{|c|c|c|c|c|c|}
\hline \multirow{2}{*}{$\begin{array}{l}\text { Symptomatology of } \\
\text { stress }\end{array}$} & \multicolumn{5}{|c|}{ Level } \\
\hline & Education & Health & Transport & Banking & $\begin{array}{c}\text { Financial } \\
\text { consultancy }\end{array}$ \\
\hline Work satisfaction & 58.8 & 56.5 & 45 & 57.6 & 51.6 \\
\hline General health & 57.6 & 33.2 & 31.2 & 53.4 & 43.2 \\
\hline Mental health & 32.2 & 20 & 17.4 & 25 & 34 \\
\hline General vitality & 52.8 & 30.8 & 22.8 & 33.8 & 32.5 \\
\hline Behavioral stress & 48.6 & 55.8 & 31.6 & 47.6 & 46.6 \\
\hline Somatic stress & 39.2 & 38.4 & 23.8 & 32.2 & 23.2 \\
\hline Cognitive stress & 37.2 & 34 & 30 & 29.6 & 25.6 \\
\hline \multirow{2}{*}{$\begin{array}{l}\text { Psychosocial risk } \\
\text { factors }\end{array}$} & \multicolumn{5}{|c|}{ Level } \\
\hline & Education & Health & Transport & Banking & $\begin{array}{c}\text { Financial } \\
\text { consultancy }\end{array}$ \\
\hline $\begin{array}{l}\text { Quantitative / } \\
\text { temporal demands }\end{array}$ & 69.2 & 58.4 & 70.6 & 66.2 & 67.4 \\
\hline Cognitive demands & 88.6 & 79.2 & 77.8 & 81.6 & 78.2 \\
\hline Emotional demands & 63.8 & 53.2 & 51 & 52.4 & 41 \\
\hline $\begin{array}{l}\text { Hiding of emotions } \\
\text { demands }\end{array}$ & 65 & 61.6 & 46.6 & 51 & 48.2 \\
\hline $\begin{array}{l}\text { Sensory-perceptual } \\
\text { demands }\end{array}$ & 90 & 86.6 & 88 & 78.6 & 75.6 \\
\hline $\begin{array}{l}\text { Demands from } \\
\text { responsibilities in } \\
\text { activity }\end{array}$ & 70 & 63.2 & 73.6 & 77.4 & 66.6 \\
\hline Influence in activity & 57 & 50 & 58.4 & 52.2 & 35.6 \\
\hline $\begin{array}{l}\text { Development } \\
\text { possibilities }\end{array}$ & 43.4 & 40.8 & 38.8 & 40.8 & 30.6 \\
\hline Degree of autonomy & 39.6 & 40 & 55.6 & 78.4 & 68.2 \\
\hline $\begin{array}{l}\text { Involvement in } \\
\text { activity }\end{array}$ & 43.8 & 31 & 44 & 37.6 & 24 \\
\hline $\begin{array}{l}\text { Degree of } \\
\text { information } \\
\text { (consult) }\end{array}$ & 39 & 41.6 & 36.6 & 42.2 & 43.2 \\
\hline
\end{tabular}




\begin{tabular}{|l|r|r|r|r|r|}
\hline Clarity of role & 25.2 & 41.8 & 23.4 & 45 & 44.5 \\
\hline Conflicts of role & 32.8 & 30 & 43.8 & 41.2 & 40 \\
\hline Management style & 45 & 45.8 & 42.2 & 48.8 & 43.2 \\
\hline $\begin{array}{l}\text { Social support (from } \\
\text { fellows and } \\
\text { superiors) }\end{array}$ & 40.2 & 33.2 & 27.2 & 52.2 & 49 \\
\hline Feedback & 37.8 & 30 & 24.4 & 48.4 & 33.2 \\
\hline $\begin{array}{l}\text { Communication } \\
\text { possibilities }\end{array}$ & 34.4 & 38.4 & 40 & 29.2 & 33.8 \\
\hline Team spirit & 34 & 41.6 & 24.4 & 29.5 & 45.4 \\
\hline $\begin{array}{l}\text { Fear of } \\
\text { unemployment }\end{array}$ & 28 & 24.4 & 58 & 56 & 53 \\
\hline
\end{tabular}

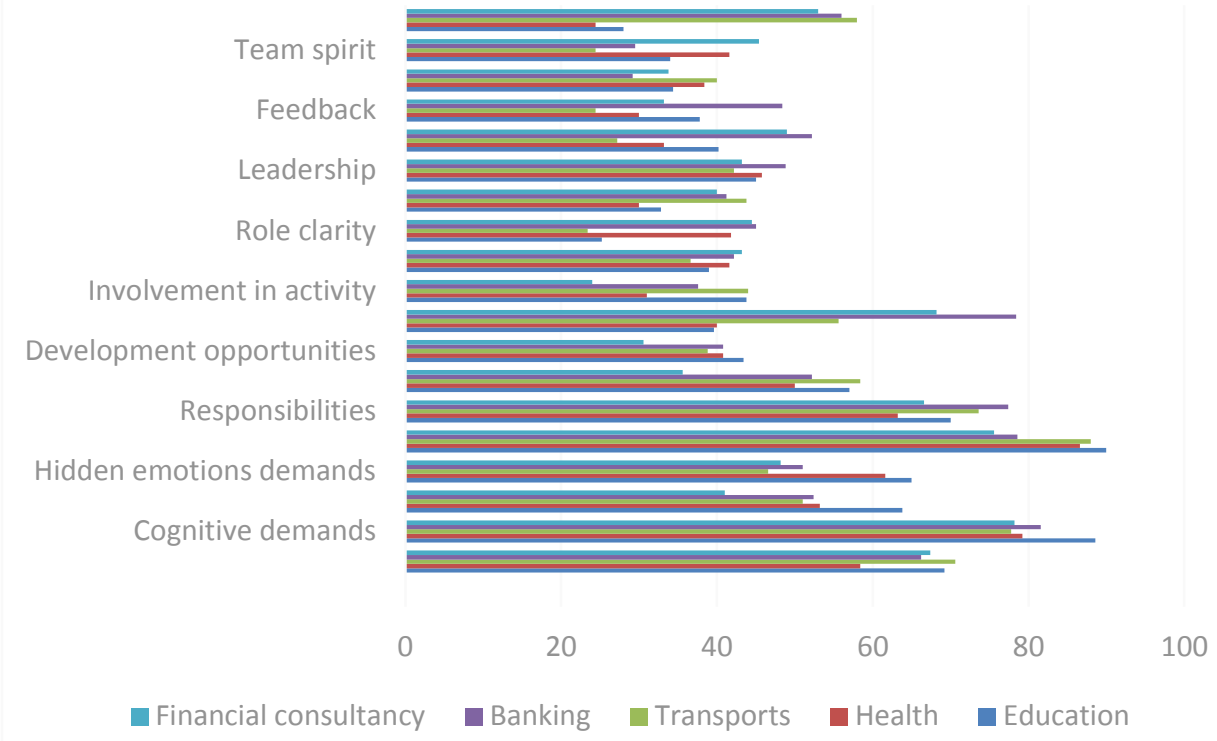

Fig. 1. Levels of psychosocial risk factors related to the field of activity 


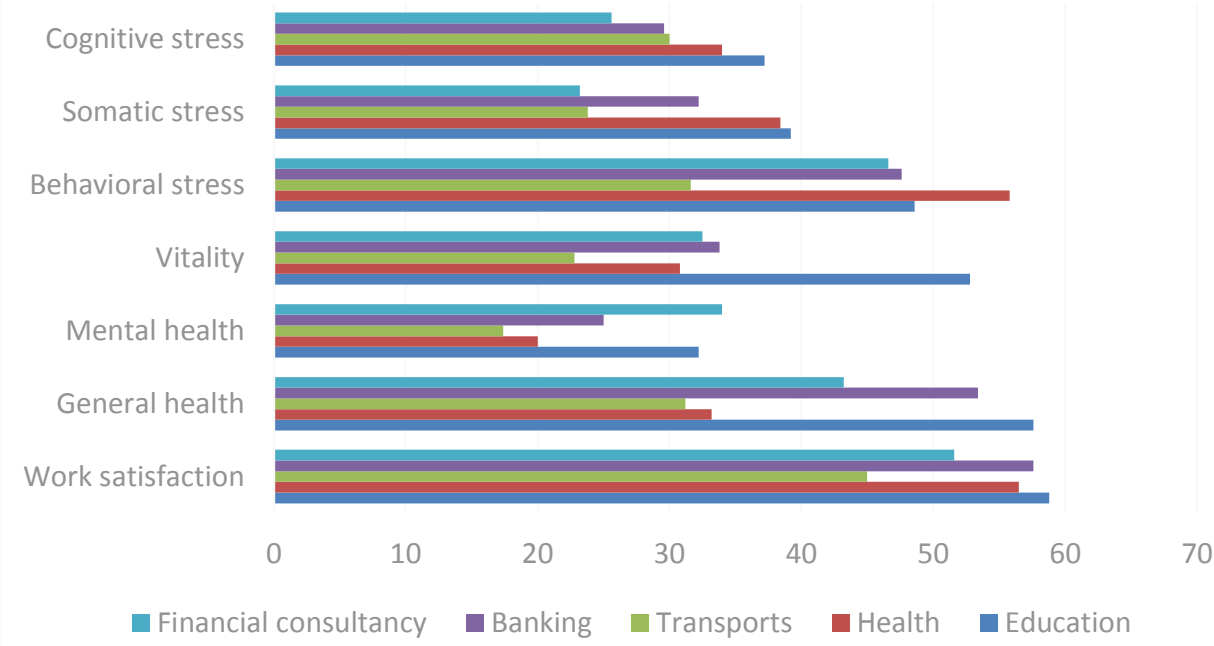

Fig. 2. Levels of stress symptoms related to the field of activity

In relation to DATO stress questionnaire, that targets evaluation of individual vulnerability to stress factors, in the plan of individual symptoms, needs and skills, the following results have been obtained:

In relation to individual symptomatology, of a somatic nature (headaches, muscular tension, fatique, appetite disorders, gastrointestinal disorders, tachycardia, hypertension, sleep disorders...) or of a psychic nature (attention disorders, irritability, nervousness, hyperactivity, frustration, anger, anxiety, depression...) no pathological findings were recorded, in any of the investigated fields.

However, a subjective symptomatology has been noticed. This symptomatology is situated in a normal range, the accused symptoms not exceeding average, hence the results are insignificant from a psychopathologic point of view:

- Education: sleeping disorders - problems getting to sleep, intermittent sleep; tachycardia; irritability; nervousness etc.

- Health: fatigue; muscular tension; irritability; frustration etc.

- Transport: muscular tension; irritability; hypertension; appetite disorders etc.

- Banking: sleeping disorders - problems getting to sleep; muscular tension; gastrointestinal disorders; hyperactivity; frustration; anxiety etc.

- Financial consultancy: headaches; fatigue; gastrointestinal disorders; hyperactivity; nervousness etc.

Individual needs (nutrition, activity, rest, protection, stability, control, acceptance, approval, understanding, identity, commitment, responsibility, accomplishment, respect...) were reported by subjects as being satisfied at a moderate level, and in some cases, at a high level.

Individual skills (sensory-perceptual, cognitive, behavioral and emotional) were perceived by the majority of subjects as being at a level of development above average, regardless of the investigated field. 


\section{Conclusions and discussions}

The study was carried out on five geographical regions (Ilfov, Sibiu, Cluj, Iași, Timiș), based on an investigation in relation to five fields of activity identified by the reports of the European Agency for Safety and Health at Work as fields in which staff is exposed more often and at a higher level, to psychosocial risk factors, also identified as stress factors. The concerned fields of activity were: education, health, transport, banking, financial consultancy.

In relation to the five fields of activity, at the level of each region, two representative organizations were randomly selected. Reprezentatives of selected organizations were instructed regarding to be applied questionnaires during information and training sessions organised by IM, together with territorial labor Inspectorates, with the participation of specialists from INCDPM "Alexandru Darabont".

Questionnaires used in the survey were distributed to the study participants, employees of the selected organizations, who were assured of the confidentiality of their answers to ensure greater accuracy of the study, thus eliminating elements of subjective variability. Questionnaires applied at the level of organizations on randomly selected lots of personnel, were collected by territorial Inspectorates and introduced for primary processing in the online database created by INCDPM "Alexandru Darabont".

The database, once constituted, has included the necessary information for secondary processing, to highlight the psychosocial risk factors/ stress factors for each field of activity in relation to which the investigation was carried out.

\section{References}

1. Brun, C., Risques psychosociaux... Stress, mal-être, souffrance. Guide pour une démarche de prévention pluridisciplinaire. ARACT Aquitaine, France (2005)

2. Cheng, Y, Regulation of psychosocial risk factors at work: An international overview. In Safety Science, 49, (2011), Online at:

http://homepage.ntu.edu.tw/ ycheng/index/PDF/reading_report/Safety $\% 20$ Science49_2 011.pdf

3. Ertel, M., Stilijanow, U., Iavicoli, S., Natali, E., Jain, A., Leka, S. European social dialogue on psychosocial risks at work: Benefits and challenges. In: European Journal of Industrial Relations, vol. 16, 2: pp. 169-183 (June 2010)

4. European Agency for Safety and Health at Work (EU-OSHA), European Survey of Enterprises on New and Emerging Risks: managing safety and health at work. European Risk Observatory Report. Office for Official Publications of the European Communities, Luxembourg (2010)

5. Leka, S., Jain, A. , Iavicoli, S., Vartia, M., Ertel, M., The role of policy for the management of psychosocial risks at the workplace in the European Union. In: Safety Science, 49, pp. 558-564, (2011)

6. Leka, S., Jain, A., Widerszal-Bazyl, M., Żołnierczyk-Zreda, D., Zwetsloot, G., Developing a standard for psychosocial risk management: PAS 1010. In: Safety Science, vol. 49, Issue 7, pp. 1047-1057, (2010)

7. Widerszal-Bazyl, M., Żołnierczyk-Zreda, D., Jain, A., PRIMA-EF. Guidance on the European Framework Psychosocial Risk Management. Chapter 3: Standards Related to Psychosocial Risks at Work. pp. 37-59, PRIMA-EF, Leka, S. and Cox ,T. (Eds.), IWHO Publications, Nottingham, UK (2008). 